\title{
УДК 37.01 \\ ДУХОВНО-КУЛЬТУРНЫЕ ЦЕННОСТИ БЕЛОРУСОВ КАК ОСНОВА МЕЖКУЛЬТУРНОЙ КОММУНИКАЦИИ В ТРАНСФОРМИРУЮЩЕМСЯ БЕЛОРУССКОМ ОБЩЕСТВЕ
}

\section{Л. В. ВОНСОВИЧ}

\author{
ИППК УО «Белорусский государственный университет физической культуры», \\ 2. Минск, Беларусь
}

Мир в эпоху глобализации значительным образом меняет свои очертания. Государства и народы подвергаются воздействию мощных информационных потоков, влиянию извне на национальную культуру. Это усложняет процесс коммуникации граждан в многонациональных государствах, нередко приводит к формированию обостренного чувства национальной принадлежности у отдельных представителей этноса, вызывает потребность отстаивать национальную идею, сохранить особенности менталитета и характера народа. В ряде стран это приводит к многочисленным конфликтам на этнической, религиозной и иной почве. Многие современные государства, реагируя на указанные выше проблемы, пытаются найти механизмы, которые могли бы способствовать утверждению мира и понимания между отдельными народами, способы межкультурной коммуникации.

Целый ряд исследователей определяет межкультурную коммуникацию как «межперсональную коммуникацию в специальном контексте, когда один участник обнаруживает культурное отличие другого. Такая коммуникация вызывает множество проблем, связанных с разницей в ожиданиях и предубеждениях, которые свойственны каждому человеку и, естественно, разные в разных культурах» [1, с. 120]. Это означает, что участники процесса коммуникации не только ориентируются на традиционную систему ценностей своего народа, живут на основе обычаев, верований, представлений своих предков, но и одновременно знакомятся, осознают и понимают особенности менталитета и характера других народов, правила и нормы их повседневного общения. Таким образом, межкультурный коммуникативный процесс выявляет как характерные, так и незнакомые свойства других культур, обозначает их отличие от традиционной культуры, выделяет тождество и инакомыслие, привычное и новое в отношениях и представлениях акторов коммуникации.

Чтобы понять особенности межкультурной коммуникации в современном белорусском обществе, следует помнить основные исторические события, способствовавшие становлению нации белорусов и формированию многонациональной государственной среды. История белорусских земель, входивших в состав различных государственных образований, наполнена многочисленными войнами, которые предопределили активность миграционных потоков. Еще в эпоху позднего средневековья на белорусских землях стали активно селиться евреи, богатства которых использовали князья Великого княжества Литовского для укрепления финансовой мощи государства. Для охраны границ, защиты территории ВКЛ активно привлекались татары, исповедовавшие ислам. В приграничных регионах традиционными были контакты представителей белорусского этноса с поляками, русскими, литовцами, украинцами. В советскую эпоху достаточно распространена была практика привлечения трудовых ресурсов в БССР, которая считалась сборочным цехом огромной державы, со всего Советского Союза. Таким образом, Беларусь изначально была территорией, где жили представители различных этносов, ориентировавшиеся на свою традиционную культуру и систему верований. Почва для общения различных народов Беларуси складывалась разными способами. Это были мирные и немирные способы взаимодействия представителей различных этносов в определенные временные эпохи и при определенных обстоятельствах. Здесь можно вспомнить и политику полонизации, навязывания католической веры жителям белорусских земель в условиях существования Речи Посполитой. Такой же негативный эффект имела и политика русификации в период вхождения белорусских земель в состав Российского государства. Памятны в истории Беларуси и еврейские погромы, и притеснения мусульманского населения. 
Сегодня белорусское государство многонационально. Согласно последней переписи населения (2019) в республике проживает более 150 наций и национальностей. Этногосударственная политика суверенной Беларуси является достаточно успешной, о чем свидетельствует отсутствие на ее территории в постсоветскую эпоху конфликтов на национальной и религиозной почве. Это также означает, что процессы межкультурной коммуникации в Беларуси в последние три десятилетия идут в позитивном ключе, что связано, как нам кажется, прежде всего с тем, что в основе существования современного белорусского общества лежит система ценностей, традиционная культура белорусов. При этом в республике признаются права представителей национальных меньшинств на этническую и культурную самоидентификацию, на использование родного языка, традиций и обычаев своего народа, на равенство с другими гражданами Беларуси перед законом. Опыт Беларуси в этом плане уникален.

Межкультурная коммуникация на территории Беларуси осуществлялась посредством интеграции народов в единое целое при сохранении собственной культурной идентичности и овладении культурой других народов. Это было предопределено геополитическим положением Беларуси, находящейся между двух цивилизаций - Западной и Восточной (Россия представляет «симбиоз «Европа-Азия»» [2, с. 13]). Именно в контексте взаимодействия культурных феноменов этих цивилизаций и шел процесс формирования белорусского этноса, складывались его отношения с другими народами. Что касается традиционной культуры белорусов, их традиционных ценностей, то они вследствие повышенной способности к саморазвитию являлись и являются определяющим фактором национального самосознания. Их, безусловно, позитивный социокультурный потенциал, и это доказывает практика повседневности, направленность на самосохранение этноса стали основой, на которой формировались принципы межкультурного взаимодействия с другими народами, живущими в Беларуси. Развитие традиционной культуры белорусов в совокупности с традиционными культурами других этносов обеспечивает возможность преодоления многих проблем и аномалий, возникших и прогрессирующих в общественной жизни современного белорусского общества. Поиск новых форм общественного согласия, становление нового формата коммуникации между гражданами, в том числе и межкультурной коммуникации народов Беларуси - вот первостепенные задачи, которые сегодня стоят на повестке дня в Республике Беларусь.

Духовно-культурные ценности белорусского народа, являющиеся своеобразным духовным стержнем общественного сознания страны и индивидуального сознания каждого гражданина, в нынешних непростых условиях подвергаются проверке на прочность. Сегодня идет открытая борьба, в том числе и за душу человека. С разных сторон подвергаются атакам нормы морали, нравственные ценности, под воздействием информационных потоков меняется мировоззрение и образ жизни людей. Зачастую национальная ценностная парадигма используется в качестве мобилизующего начала, способствующего как позитивной, так и негативной активности человека в утверждении его жизненной позиции. Эту ситуацию возможно исправить, если обратиться к традиционной культуре народа, лучшим его качествам, религии, прежде всего христианской, которая всегда была признанным общественным и культурным феноменом, обладающим мощным воспитательным потенциалом.

Будучи неотъемлемым структурным компонентом исторической традиции народа, религия воздействовала и продолжает воздействовать на чувства, эмоции, переживания людей, их настроение и отношение к миру, в котором они живут. История белорусских земель свидетельствует о длительном сосуществовании различных конфессий на территории Беларуси, что, безусловно, также способствовало коммуникации наших предков с другими народами. При этом именно вероучение христиан, которые в количественном отношении доминировали, в большей степени, чем тот же национальный фактор, влияло на духовные процессы в обществе и в конечном итоге способствовало утверждению веротерпимости, которая сегодня доминирует в сознании большинства граждан Беларуси. 
В условиях кризисного состояния современного белорусского общества именно ценности христианской духовной традиции могут стать определяющими в выборе направленности действий и поступков людей. Опора должна идти на такие ценностные ориентиры, четко зафиксированные в генетическом коде белорусов, на миролюбие, уважительное отношение к человеку, имеющему иное миропонимание, другой цвет кожи, национальную и религиозную принадлежность, иные убеждения и взгляды. Это также просвещенность, гуманность, стремление служить родной земле, духовное совершенствование. И здесь уместно апеллировать к трудам известных восточнославянских мыслителей Ефросиньи Полоцкой, Кирилла Туровского, Сымона Будного, Василия Тяпинского и многих других. В их понимании важнейшей добродетелью индивида является человеколюбие. Его проявление возможно в прощении тех, кто нанес обиду, в заботе о своих близких, в оказании помощи тому, кто в этом нуждается, во взаимоуважении интересов и чувств других людей. Человек нравственный желает добра другому человеку, подкрепляя это желание реальными поступками, поскольку «любовь к Богу не в словах совершается, а в действительных делах» [3, с. 157], а «братьями являются те, кто в беде помогает друг другу» [3, с. 158].

Среди духовно-культурных ценностей белорусского общества, берущих начало в христианском вероучении и в исторической памяти народа, приоритетом, который не подвергается сомнению и у нынешнего поколения, является ценность Родины, Отечества, понимаемых как родная земля. Родной Беларусь является не только для белорусов, но и многих других народов, живущих веками на ее территории. Преданность родной земле рождает определенные чувства и настроения людей : гордость - за ее свершения, разочарование - за неудачи, мобилизует на защиту ее целостности и суверенитета, способствует развитию патриотизма. Актуальными и сегодня являются слова основоположника морально-патриотической традиции в общественно-политической мысли белорусских земель, гуманиста и просветителя Франциска Скорины, утверждавшего, что «... люди, игде зродилися и ускормлены суть по бозе, к тому месту великую ласку имеють» [4, с. 45]. Патриотические чувства белорусов, передающиеся от поколения к поколению, основаны на любви к родной земле. В них нет примеси крайнего национализма, абсолютизации своей национальной избранности. Белорусский патриотизм ориентирован на гармоничное развитие титульной нации и других народов, проживающих на их родной земле, на уважение национальных и местных традиций, исторического прошлого, народных обычаев и культуры, на плодотворную межкультурную коммуникацию.

Значимой в жизни белорусов ценностью является толерантность, на которой в последнее время акцентируется все больше внимания. Терпимое отношение белорусов к другим людям, событиям, явлениям обусловлено политикой гнета и притеснения белорусского народа, целые поколения которого вынуждены были приспосабливаться к постоянно меняющейся политической ситуации, выживать, сохранять свои корни, оберегать свои семьи, своих детей. Это выработало со временем определенный генетический код белорусской нации, представители которой ориентированы на мир и согласие, не приемлют насилия и негуманного отношения к человеку, тяготеют к справедливости, к стабильному настоящему и предсказуемому будущему. Современные белорусы длительное время поддерживали власть, которая не допускала крайностей в политике и давала гражданам возможность самим определять путь развития государства и свой жизненный путь. Власть, отошедшая от данных принципов, имеет шансы потерять свои доминирующие позиции в обществе. В основе государственного курса Республики Беларусь на данном этапе должны лежать «верность исторической памяти народа и последовательная политика по сохранению и развитию культурного наследия белорусов» [5, с. 134], живущих в тесном единстве с другими народами - коммуникаторами в системе межкультурной коммуникации.

Таким образом, уважение духовно-культурных традиций белорусов со стороны представителей других этносов, живущих в Беларуси, признание белорусами существования разнообразия культур является основанием взаимоуважения различных народов, источником 
не только сохранения, но и подъема культурного потенциала общества. Благодаря этому обеспечивается успешность межкультурной коммуникации в государстве, появляется возможность противостоять унификаторскому влиянию процессов глобализации, полнее раскрыть творческий потенциал людей, создать условия для эффективного функционирования разнообразных институтов и процессов, продвижению Беларуси по пути устойчивого развития.

В условиях трансформации белорусского общества важным видится формирование новой культуры и человека с новым типом мышления. В этом плане традиционная культура белорусов содержит «народный идеал совершенного человека» [6, с. 102], образец идеальной личности, которую отличает высокая нравственность, совершенное духовное и физическое развитие. Белорусы способны преодолеть те трудности, которые возникли на их пути, проявляя волевые черты характера своих предков - упорство, терпеливость, настойчивость, трудолюбие, уважительное отношение к представителям других культур. Интегрирующим моментом в жизнедеятельности белорусского общества, с одной стороны, должно стать формирование национального самосознания народа, укоренение в его миропонимании традиционных понятий (Родина, семья, народ, вера, история), определяющих духовную жизнь нации. С другой стороны, должны быть созданы благоприятные условия для включения граждан Беларуси в прошлое и настоящее мировой культуры на основе диалога культур, открытой коммуникации в духе взаимоуважения и взаимопонимания.

\section{Литература}

1. Спирина, М. Ю. Традиционная культура как основа межкультурной коммуникации на евразийском пространстве. [Электронный ресурс]. - Режим доступа : file://CC:/Users/ivanova_o/Downloads/traditsionnaya-kultura-kak-osnova-mezhkulturnoykommunikatsii-na-evraziyskom-prostranstve.pdf - Дата доступа : 15.10.2020.

2. Фишман, О. Л. Китай в Европе: миф и реальность (XIII-XVIII вв.) / О. Л. Фишман - СПб. : Петербургское востоковедение, 2003. - 544 с.

3. Печерский, Ф. Слово о терпении и любви / Ф. Печерский // Златоструй. Древняя Русь Х-ХІІІ вв. - М. : Молодая гвардия, 1990. - С. 154-156.

4. Скарына Францыск. Творы: Прадмовы, сказанні, пасляслоўі, акафісты, пасхалія / Уступ. арт., падрыхт. тэкстаў, камент., слоўнік А. Ф. Коршунава. - Мінска : Асвета, 1990. - 206 с.

5. Вонсович, Л. Традиционные ценности народа как основа воспитательного процесса современной образовательной системы Республики Беларусь // Современное образование: преемственность и непрерывность образовательной системы «школауниверситет-предприятие». [Электронный ресурс] : XI международная научнометодическая конференция, Гомель, 23-24 ноября 2017 г. : материалы. - Электрон. текст. дан. (объем 6,46 Mb). - Гомель : ГГУ им. Ф. Скорины, 2017. - 1 электрон. опт. диск (CD-ROM). - Систем. требования: IBM-совместимый компьютер; Windows XP; O3У 512 Mb; CD-ROM 8-х и выше. - Загл. с этикетки диска. - C. 130-134.

6. Панарин, А. С. Стиль «ретро» в идеологии и политике. (Критические очерки французского неоконсерватизма) / А. С. Панарин - М. : Мысль, 1989. - 220 с.

Статья посвящена проблеме межкультурной коммуникации в трансформирующемся белорусском обществе. Рассматривается роль традиционной культуры, духовно-культурных ценностей белорусов в коммуникационных процессах на территории современной Беларуси.

The article is devoted to the problem of intercultural communication in the transforming Belarusian society. It indicates the role of traditional culture, spiritual and cultural values of Belarusians in communication processes on the territory of modern Belarus. 